\title{
Implikasi Putusan Mahkamah Konstitusi Nomor 36/PUU-XV/2017 terhadap Kedudukan KPK sebagai Lembaga Negara Independen
}

\author{
Asrizal $^{*}$, Sobirin Malian ${ }^{2}$ \\ 1 Fakultas Hukum Universitas Ahmad Dahlan, Indonesia \\ 2 Fakultas Hukum Universitas Ahmad Dahlan, Indonesia \\ *Corresponding Author: Asrizalnilardin@gmail.com
}

\begin{tabular}{|c|c|}
\hline Histori Artikel & Abstrak \\
\hline $\begin{array}{l}\text { Masuk: } 07 \text { Jun } 2021 \\
\text { Review: } 01 \text { Sep } 2021 \\
\text { Diterima: } 08 \text { Okt } 2021 \\
\text { Terbit: } 19 \text { Okt } 2021\end{array}$ & $\begin{array}{l}\text { Tujuan dari penelitian ini ialah untuk mengetahui } \\
\text { Implikasi Putusan Mahkamah Konstitusi Nomor } \\
\text { 36/PUU-XV/2017 terhadap kedudukan KPK sebagai } \\
\text { Lembaga Negara Independen dalam Struktur } \\
\text { Ketatanegaraan Indonesia. Metode penelitian yang } \\
\text { digunakan dalam penelitian ini adalah penelitian } \\
\text { hukum normatif/doktrinal dengan pendekatan } \\
\text { perundang-undangan (statute approach), pendekatan } \\
\text { analitis (analytical approach), pendekatan kasus (case } \\
\text { approach). Teknik pengumpulan data dilakukan dengan } \\
\text { cara penelitian kepustakaan (library research) dan } \\
\text { analisis data menggunakan deskriptif kualitatif. Hasil } \\
\text { penelitian ini menjelaskan bahwa Putusan MK Nomor } \\
\text { 36/PUU-XV/2017 yang menempatkan KPK sebagai } \\
\text { lembaga negara yang kedudukan dan kebera daannya } \\
\text { berada pada cabang kekuasaan eksekutif telah } \\
\text { menimbulkan problem kedudukan dan relasi } \\
\text { kelembagaan KPK. Akibatnya hakangketyang diajukan } \\
\text { oleh DPR terhadap KPKadalah merupakan pelaksanaan } \\
\text { dari fungsi pengawasan legislatif terhadap cabang } \\
\text { kekuasaan eksekutif (pemerintah). Selain itu putusan } \\
\text { tersebut telah menjadi dasar atas revisi UU KPK yang } \\
\text { menegaskan kedudukan KPK sebagai Lembaga negara } \\
\text { dalam rumpun eksekutif. Putusan tersebut menegaskan } \\
\text { pengadopsian teori pemisahan kekuasaan (separation } \\
\text { of power) dalam struktur ketatanegaraan Indonesia } \\
\text { dengan konsepsi dasar trias politica. Implikasi putusan } \\
\text { MK Nomor } 36 / P U U-X V / 2017 \text { menimbulkan persoalan } \\
\text { mengenai independensi KPK secara institusional dalam } \\
\text { kelembagaan Indonesia. Menempatkan KPK sebagai } \\
\text { lembaga eksekutif pada hakikatnya telah } \\
\text { menghilangkan independensi kelembagaan KPK. Selain } \\
\text { itu, putusan a quo berimplikasi pada kedudukan } \\
\text { lembaga negaraindependen lainnya. Denganpenegasan } \\
\text { dalam putusan a quo bahwa semua lembaga negara }\end{array}$ \\
\hline
\end{tabular}




\section{Ahmad Dahlan Legal Perspective}

Volume 01, Issue 02, 2021, pp. 129-144

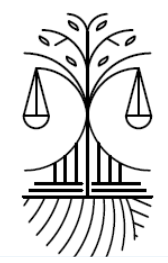

independen harus diklasifisi dalam model trias politica.

Kata Kunci: Implikasi; Putusan; Trias Politica; Lembaga; Independen.

\begin{tabular}{|c|c|}
\hline Article's History & Abstract \\
\hline $\begin{array}{l}\text { Received: 07 Jun } 2021 \\
\text { Reviewed: } 01 \text { Sep } 2021 \\
\text { Accepted: } 08 \text { Okt } 2021 \\
\text { Published: } 19 \text { Okt } 2021\end{array}$ & $\begin{array}{l}\text { The purpose of this study is to determine the legal } \\
\text { implications of the Constitutional Court Decision Number } \\
36 / P U U-X V / 2017 \text { on the position of the KPK as an } \\
\text { Independent State Institution in the Indonesian } \\
\text { Constitutional Structure. The research methods used in } \\
\text { thisresearch are normative/doctrinal legal research with } \\
\text { a statute approach, analytical approach, case approach. } \\
\text { Data collection techniques are carried out by means of } \\
\text { library research and data analysis using qualitative } \\
\text { descriptive. The results of this study explain that the } \\
\text { Constitutional Court Decision Number } 36 / P U U \text {-XV/2017, } \\
\text { places the KPK as a state institution whose position and } \\
\text { existence is in the executive branch of power, as a result } \\
\text { the right of inquiryproposed by the DPR against the KPK } \\
\text { is the implementation ofthelegislative oversight function } \\
\text { of the branch of power. (executive).In addition, theruling } \\
\text { has become the basis for the revision of the KPK Law } \\
\text { which affirms the KPK's position as a state institution in } \\
\text { the executive organ. This decision clearly contradictsthe } \\
\text { conception of Indonesia's constitutional structure which } \\
\text { does not strictly adhere to the trias politica theory. the } \\
\text { implications of the Constitutional Court's decision } \\
\text { Number 36/PUU-XV/2017, the independence of the KPK } \\
\text { can nolonger be said to be independentin the true sense } \\
\text { (institutional independence), the position of the KPK as } \\
\text { an executive institution has essentially eliminated the } \\
\text { institutional independence ofthe KPK. The a quo decision } \\
\text { also affects the position of other independent state } \\
\text { institutions, all independent state institutions must be } \\
\text { classified into the trias politicabranch. }\end{array}$ \\
\hline
\end{tabular}

Keywords: Implications; Decision; trias politica; Institution; Independent.

All articles are published online in http://iournal2.uad.ac.id/index.php/adlp/

\section{Pendahuluan}

Pada negara-negara monarki absolut, kekuasaan negara tersentral pada satu cabang kekuasaan yang memiliki kewenangan tak terbatas. Dalam praktiknya kerap terjadi penyimpangan dan penyalahgunaan kekuasaan oleh raja yang berkuasa. Potensi penyelewengan dan penyalahgunaan kekuasaan akan selalu ada dari kekuasaan yang tak terbatas. Memperingatkan kecenderungan itu, Lord Acton mengatakan "power tends to corrupt and absolute power corrupts 
absolutely". Untuk membatasi kekuasaan raja yang absolut tersebut, lahir teori pembatasan kekuasaan yang dicetus John Locke, kemudian dikembangkan dengan model separation of power atau yang dikenal dengan teori Trias politica oleh Montesquie yang memisahkan kekuasaan negara ke dalam tiga cabang kekuasaan (Sugianto, 2018:15).

Teori trias politica Montesquie menjadi dasar pijakan bagi negara-negara demokarasi modern untuk membatasi kekuasaan agar tidak terpusat dan tersentral di satu cabang kekuasaan saja, melainkan dipisah ke dalam tiga cabang kekuasaan yang disebut, kekuasaan legislatif, kekuasaan eksekutif, dan kekuasaan yudikatif yang menjalankan fungsi secara terpisah. (Miriam Budiardjo, 2003:156).

Kekuasaan legislatif dijalankan Bersama-sama oleh DPR, DPD dan MPR, kekuasaan eksekutif dilaksanakan oleh Presiden dan Wakil Presiden yang dibantu oleh menteri-menterinya, dan kekuasaan yudikatif dilaksanakan oleh Mahkamah Agung dan Mahkamah Konstitusi. Pasca amandemen UUD NRI 1945, ketiga cabang kekuasaan itu disebut sebagai lembaga negara utama yang saling mengontrol dan mengimbangi (checkand Balances) satu sama lain agar tidak terjadi penyelewengan kekuasaan (abuse of power) (Jimly Asshiddiqie, 2015: 284).

Indonesia selain dikenal lembaga negara utama, juga dikenal lembaga negara independen, beberapa lembaga negara independen tersebut ada yang nama dan atau kewenangan serta fungsinya disebut dan dijelaskan dalam UUD NRI 1945, adapula yang pembentukannya hanya melalui Undang-Undang, Peraturan Pemerintah, Keputusan Presiden atau Peraturan Daerah. Keberadaan lembaga-lembaga negara independen tersebut adalah untuk membantu atau menjadi penunjang dari lembaga negara utama (axualliery staat organ) (Ni'matul Huda, 2007:76).

Beragam peristilahan yang digunakan untuk menyebut lembaga negara independen. Dalam konstitusi tidak ada terminologi tunggal untuk menyebut peristilahan lembaga negara. Terkadang ada yang menyebutnya dengan istilah badan negara, organ negara, lembaga negara, komisi negara, dan alat perlengkapan negara (Ni'matul Huda, 2007:77).

Salah satu lembaga negara independen yang paling eksis di Indonesia ialah Komisi Pemberantasan Korupsi (KPK). Kelahiran KPK merupakan salah satu dari agenda besar reformasi. Pembentukan KPK sebagai tindak lanjut dari tuntutan reformasi yang bertujuan mewujudkan penyelenggaraan negara yang bebas dari KKN yang telah menjadi darurat dan menggurita selama rezim orde baru berkuasa. 


\section{Ahmad Dahlan \\ Legal Perspective}

Volume 01, Issue 02, 2021, pp. 129-144

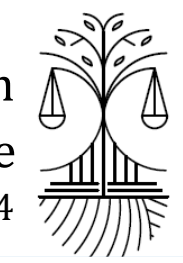

Kelahiran KPK sebagai politik hukum guna merespon dan memberantas tindak pidana korupsi. Pada konsideran menimbang Undang-Undang No.30 Tahun 2002, Kelahiran KPK sebagai reaksi terhadap tidak efektif dan efisiennya fungsi penanganan perkara tindak pidana korupsi yang dilakukan oleh lembaga pemerintah (Kejaksaan dan Kepolisian).

Praktik KKN adalah warisan problem yang diberikan oleh rezim Orde Baru. Problem ini yang menjadi salah satu pemicu kuat atas runtuhnya rezim Orde Baru yang pada akhirnya melangkah masuk ke reformasi. Di era Soeharto, sejalan dengan otoriter kekuasaannya, korupsi tersentralisasi dan menumpuk pada keluarga Soeharto dan orang terdekat. Terkait dengan hal tersebut, Tim Lindsey (2002) secara sinis menyebut korupsi di zaman Orde Baru telah menjadi sistem yang menjalankan negara, meski secara informal. Hal ini yang semakin mengukuhkan korupsi sebagai kebiasaan buruk oleh pejabat publik baik ditingkat yudikatif, eksekutif, maupun legislatif (Zainal Arifin Mochtar, 2016:81-82).

Perdebatan tentang kedudukan dan keberadaan KPK dalam struktur ketatanegaraan Indonesia masih menimbulkan pro dan kontra. Beberapa pihak menilai bahwa KPK adalah lembaga negara independen yang berada di luar dari cabang kekuasaan eksekutif, legislatif, atau pun yudikatif. Penilaian tersebut berangkat dari fungsi kelembagaan KPK yang menjalankan fungsi campuran (quasi eksekutif dan quasi yudikatif). Sebaliknya, ada pula yang berpendapat bahwa kehadiran KPK adalah bagian dari kekuasaan eksekutif karena KPK merupakan lembaga pelaksana Undang-Undang. Setelah diundangkan UU No.19 Tahun 2019 tentang perubahan atas UU No.30 tahun 2002 tentang KPK, status kelembagaan KPK secara tegas telah dimaknai sebagai bagian dari rumpun kekuasaan eksekutif. Namun sebelum itu, Mahkamah Konstitusi telah mengeluarkan putusan Nomor 36/PUU-XV/2017, dalam pokoknya selain menolak permohonan pemohon, MK juga menyampaikan pertimbangan hukumnya yang secara tegas menyatakan bahwa KPK masuk ke dalam ranah kekuasaan eksekutif. Oleh karena itu, Mahkamah beranggapan KPK dapat menjadi objek angket DPR.

Kendati dalam putusan a quo MK menolak permohonan para pemohon dan menyatakan KPK bagian dari cabang kekuasaan eksekutif, namun suara sembilan hakim MK tidak bulat. Terdapat empat hakim MK yang berbeda pendepat (dissenting opinion) terhadap penggunaan hak angket DPR terhadap KPK in casu. Adapun empat hakim yang menyatakan dissenting opinion, yakni hakim Saldi Isra, I Dewa Gede Palguna, Suhartoyo dan Maria Farida.

Pendapat yang sama juga dikemukakan oleh mantan ketua MK Mahfud MD, yang menegaskan bahwa putusan tersebut bertentangan dengan empat 
putusan MK sebelumnya, yakni putusan Nomor 012-016/PUU- IV/2006, putusan Nomor 19/PUU-V/2007, putusan Nomor 37- 39/PUU-VIII/2010, dan putusan Nomor 05/PUU-IX/2011. Dalam keempat putusan tersebut menegaskan bahwa KPK merupakan lembaga independen yang bukan berada diranah eksekutif, legislatif, dan yudikatif.

Dari uraian tersebut di atas, putusan Mahkamah Konstitusi Nomor 36/PUU$\mathrm{XV} / 2017$ telah secara tegas mengklasifikasi kedudukan KPK dalam struktur ketatanegaraan Indonesia sebagai bagian dari cabang kekuasaan eksekutif. Hal itu berimplikasi terhadap independensi kelembagaan KPK sebagai lembaga negara independen yang diidealkan berada di luar dari model kelembagaan trias politika klasik. Apabila kelembagaan KPK berada pada rumpun kekuasaan eksekutif, maka keberadaannya berada di bawah kekuasaan presiden sebagai kepala eksekutif. Selain itu, putusan a quo, telah membuat desain kelembagaan Indonesia menjadi sangat tersentral. Artinya semua lembaga negara independent lain, seperti KPU, KY, Bawaslu, Ombudsman dan lain-lain harus diklasifikasi ke dalam model kelembagaan trias politika. Namun demikian, jika dicermati secara historis dalam rumusan awal kelembagaan Indonesia dan juga mengacu pada dinamika perkembangan ketatanegaraan modern, sejatinya Indonesia tidak menganut secara kaku model pemisahan kekuasaan yang hanya tersentral pada tiga cabang kekuasaan negara. Maka menjadi sangat penting penelitian ini untuk menganalis lebih lanjut mengenai hal tersebut.

\section{Metodologi}

Penelitian ini menggunakan metode penulisan yuridis-normatif dengan pendekatan konsep (conceptual approach), dan pendekatan kasus (case approach) untuk menjawab permasalahan di atas. Adapun konsep yang ditelaah adalah konsep trias politica, konsep separation of power, konsep auxiliary state organ, konsep lembaga negara, dan konsep kedudukan KPK sebagai Lembaga negara independen. Pendekatan Kasus (case approach) dilakukan dengan cara melakukan telaah terhadap putusan Mahkamah Konstitusi. Jenis penelitian tersebut dipilih karena didalam penelitian ini mengkaji sumber-sumber hukum positif, yakni UUD NRI 1945, UndangUndang No 30 Tahun 2002 sebagaimana telah diubah dengan Undang-Undang Nomor 19 Tahun 2019 tentang KPK dan Putusan Mahkamah Konstitusi Nomor 36/PUU-XV/2017.

Hasil dan Analisis

Dinamika Pembentukan Komisi Pemberantasan Korupsi 


\section{Ahmad Dahlan \\ Legal Perspective}

Volume 01, Issue 02, 2021, pp. 129-144

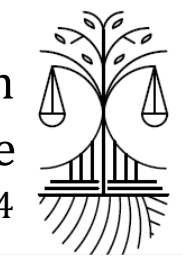

Komisi Pemberantasan Tindak Pidana Korupsi (KPK) merupakan lembaga negara yang lahir di era reformasi, kelahiran lembaga ini salah satu dari agenda besar reformasi, yakni upaya untuk mewujudkan penyelenggaraan negara dan pemerintahan yang bersih dan bebas dari korupsi.

Pada rezim pemerintahan Orde Baru berkuasa, dalam penyelenggaraan negara telah terjadi praktik-praktik usaha yang lebih menguntungkan kelompok tertentu yang menyuburkan korupsi, kolusi dan nepotisme yang melibatkan pejabat negara dengan para pengusaha yang merusak sendi-sendi penyelenggaraan negara dalam berbagai aspek kehidupan nasional (Ni'matul Huda, 2007:223). Embrio kelahiran KPK sudah dimulai sejak tahun 1998. Pada saat rapat paripurna keempat pada tanggal 13 November 1998. MPR mengeluarkan ketetapan No.XI/MPR/1998 tentang penyelenggaraan negara yang bersih dan bebas KKN. Tindak lanjut dari ketetapan tersebut, maka disahkan UU No. 28 Tahun 1999 tentang Penyelenggaraan Negara yang Bersih dan Bebas dari KKN. Lebih lanjut, UU tersebut kemudian mengamanatkan kepada Presiden sebagai kepala pemerintahan untuk membentuk sebuah Komisi Pemeriksaan yang bertugas melakukan pemeriksaan terhadap harta kekayaan pejabat negara, dan komisi tersebut bertanggungjawab langsung kepada Presiden (H.M. Thalhah \& Sobirin Malian, 2011: 119-120).

Sebagai tindak lanjut dari lahirnya Ketetapan MPR tersebut, maka lahirlah Undang-Undang No.28 Tahun 1999 tentang Penyelenggaraan Negara yang bersih dan bebas dari Korupsi, Kolusi dan Nepotisme. Undang-Undang ini mengamanatkan kepada Presiden selaku sebagai kepala negara untuk membentuk sebuah komisi pemeriksa yang bertanggungjawab kepada presiden yang mempunyai tugas dan wewenang untuk melakukan pemeriksaan terhadap kekayaan pejabat negara sebelum, selama, dan setelah menjabat, termasuk meminta keterangan baik dari mantan pejabat Negara, keluarga kroninya, maupun para pengusaha, dengan tetap memperhatikan praduga tak bersalah dan prinsip hak asasi manusia (Ni'matul Huda, 2007:223).

Gelombang reformasi yang terjadi pada tahun 1998 telah banyak menunjukan bahwa sudah timbul kesadaran secara nasional untuk menjadikan Korupsi, Kolusi, dan Nepotisme (KKN) sebagaimana musuh bersama. Adanya tuntutan masyarakat untuk melakukan menyelidi korupsi terhadap para "pejabat hitam" di masa orde baru berkuasa. Guna menindaklanjuti tuntutan itu, maka didirikanlah berbagai badan atau komisi untuk mencegah atau mengusut tuntas tindak pidana korupsi. Beberapa diantaranya ialah lahirnya Komisi Pengawas Kekayaan Pejabat Negara (KPKPN) dan Tim Gabungan 
Pemberantasan Tindak Pidana Korupsi (TGPTPK) (Diana Napitupulu, 2018:45-46).

Pembentukan komisi pemeriksa kekayaan pejabat negara yang bertanggungjawab kepada Presiden dalam melakukan pemeriksaan terhadap harta kekayaan para penyelenggara negara. Tugas komisi meliputi sebelum, selama dan setelah pejabat negara menjabat. Ruang lingkup tugas komisi diatur dalam Undang-Undang No.28 Tahun 1999. Setelah Undang-Undang tersebut, lahirlah Undang-Undang No.31 Tahun 1999 yang kemudian menggantikan Undang-Undang No.3 Tahun 1971 tentang Pemberantasan Tindak Pidana Korupsi.

Terbitnya Undang-Undang No.31 Tahun 1999 merupakan upaya peningkatan dan antisipasi terhadap kebutuhan hukum masyarakat dalam rangka mencegah dan memberantasan secara lebih efektif setiap bentuk tindak pidana korupsi. Sebagai kelanjutannya, sebagaimana yang terkandung dalam Pasal 43, mengamanatkan pembentukan Komisi Pemberantasan Tindak Pidana Korupsi yang akan diatur dalam Undang- Undang tersendiri dalam jangka waktu paling lama 2 (dua) tahun sejak Undang-Undang ini diundangkan (Ni'matul Huda, 2007: 225).

Sebagai tindak lanjut atas amanat Undang-Undangg No.31 Tahun 1999 Pasal 43 tersebut, pada tanggal 27 Desember 2002 lahirlah Undang- Undang No.30 Tahun 2002 tentang Komisi Pemberantasan Tindak Pidana Korupsi, yang kemudian disebut Komisi Pemberantasan Korupsi (KPK). Pembentukan komisi ini dimaksudkan untuk mengatasi kemacetan hukum dalam kasus korupsi yang sebelumnya dilaksanakan oleh polisi dan jaksa namun tidak efektif dalam menyelesaikan kasus korupsi (Ni'matul Huda, 2007: 226).

Dengan Undang-Undang No.30 Tahun 2002, nama Komisi Pemberantasan Tindak Pidana Korupsi yang kemudian selanjutnya disebut Komisi Pemberantasan Korupsi (KPK). Status hukum komisi ini secara tegas ditentukan sebagai lembaga Negara yang dalam menjalankan tugas dan wewenang bersifat independen dan bebas dari pengaruh kekuasaan manapun. Pembentukan komisi ini bertujuan untuk meningkatkan daya guna dan hasil guna upaya pemberantasan tindak pidana korupsi. Dalam menjalankan tugas dan wewenang, komisi bekerja berdasarkan asas- asas: (a) kepastian hukum, (b) keterbukaan, (c) akuntabilitas, (d) kepentingan umum, dan (e) proporsionalitas (Jimly Asshiddiqie, 2010:194).

Namun, pasca dilakukan revisi terhadap Undang-Undang No.30 Tahun 2002 dengan Undang-Undang No.19 Tahun 2019 tentang KPK, telah mengubah struktur kelembagaan KPK menjadi bagian dari cabang kekuasaan pemerintah. Pada Pasal 3 UU No.19 Tahun 2019 menegaskan KPK adalah 


\section{Ahmad Dahlan \\ Legal Perspective}

Volume 01, Issue 02, 2021, pp. 129-144

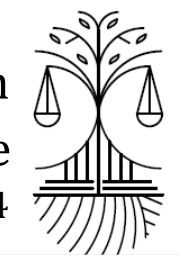

lembaga negara dalam rumpun kekuasaan eksekutif. Ketentuan tersebut juga menindaklanjuti tafsiran MK dalam putusan Nomor 36/PUU-XV/2017. Dengan demikian, eksistensi independensi kelembagaan KPK menjadi amat problematis. Independen yang ideal mengalami reduksi yang berimplikasi pada fungsi dan wewenang KPK.

Motif kelahiran KPK akibat tidak efektif dan efisiennya institusi-institusi yang menangani tindak pidana korupsi, serta belum menunjukan hasil yang optimal dalam menekan angka tindak pidana korupsi yang kian memperburuk kehidupan perekonomian negara, maka dengan spirit menciptakan penyelenggaraan negara yang bersih dan bebas dari perilaku korupsi, KPK hadir sebagai institusi harapan (Mellysa Febriani Wardojo, 2018: 75).

Pembentukan KPK merupakan tuntutan reformasi guna mencegah dan memberantas tindak pidana korupsi yang sebelumnya menjadi momok dan musuh Bersama, masyarakat sudah muak dengan perilaku korupsi yang mewabah dan merajalela dalam lingkaran kekuasaan rezim orde baru. Kelahiran KPK pada dasarnya adalah akibat tidak efektif, efisien, dan optimalnya pemberantasan tindak pidana korupsi yang dilakukan oleh kepolisian dan kejaksaan yang sebelumnya mengalami kemacetan dalam pemberantasan korupsi.

\section{Kedudukan KPK dalam Struktur Ketatanegaraan Indonesia}

Sebagai lembaga negara yang bertugas untuk melakukan pencegahan dan pemberantasan tindak pidana korupsi, KPK dinilai sebagai lembaga negara yang keberadaannya sangat strategis dalam struktur ketatanegaraan Indonesia. Bagaimana tidak, wabah korupsi yang masih menjangkit dan menghambat perkembangan serta kemajuan Negara merupakan ancaman serius bagi kelangsungan kesejahteraan dalam kehidupan berbangsa dan bernegara.

Keberadaan KPK adalah solusi alternatif atas instansi kepolisian dan kejaksaan yang sebelumnya mengalami public distrust akibat banyaknya aparat kepolisian dan kejaksaan yang terlibat dalam perilaku korupsi. Kehadiran KPK diharapkan dapat mengatasi kemacetan pencegahan dan pemberantasan perilaku korupsi yang dilakukan oleh pejabat negara yang sebelumnya tugas itu dilakukan oleh kejaksaan dan kepolisian.

Kendati dalam Putusan Nomor 36/PUU-XV/2017, Mahkamah Konstitusi secara tegas telah mengklasifikasi dan memperjelas posisi keberadaan KPK sebagai lembaga negara yang berada dalam lingkup kekuasaan eksekutif. Namun demikian, putusan itu masih mendapat pro dan kontra secara teoritis. Dalam putusan a quo MK menegaskan kedudukan KPK dalam struktur 


\section{Ahmad Dahlan}

ketatanegaraan Indonesia adalah sebagai lembaga negara yang berada dalam lingkup kekuasaan eksekutif namun bersifat independen dalam melaksanakan tugas dan wewenang.

Sebagai lembaga negara yang sifat independensi KPK secara tegas dalam Undang-Undang. Hal tersebut untuk memastikan bahwa KPK dalam menjalankan tugas dan wewenang dapat dilaksanakan secara professional, intensif, dan berkesinambungan yang bebas dari pengaruh kekuasaan manapun.

Jika merujuk pada motif dan rumusan norma pembentukan Undang-Undang KPK, dapat dimaknai politik hukum atau harapan pembentuk Undang-Undang ketika menentukan kedudukan KPK sebagai lembaga negara independen. Penegasan akan independensi KPK sebagai lembaga negara yang melakukan pencegahan dan pemberantasan korupsi dapat dilacak dari risalah pembentukan Undang-Undang Nomor 30 Tahun 2002 tentang KPK.

Salah satu usul yang menarik datang dari Firman Jaya Daeli (F- PDIP) sebagaimana yang dikutip (dalam Zaenal Arifin Mochtar 2016:86), yang mengingatkan bahwa berbicara soal KPK adalah berbicara tentang pelembagaan yang luar biasa kuat untuk melakukan pencegahan dan pemberantasan korupsi yang sesuai dengan amanat Tap MPR XI/1998. Dengan demikian, ia mengusulkan untuk lebih banyak berbicara atau menganalisis dari sisi tema sentral perlunya extra ordinary crime. Lebih lanjut ia menekankan untuk pertama dibahas ialah terkait independensi komisi, sebagaimana yang ia ungkapkan,"Menurut kami yang pertama adalah bahwa ini komisi independen, special commission itu, national commission itu, independent commission itu, itu dulu, itu yang pertama". Menurut Emong Komariah Sapardjaya, yang menjadi tim ahli pada rapat panja RUU KPK, mengingatkan tentang pentingnya kehadiran lembaga negara independen seperti KPK adalah dalam rangka menjawab tuntutan masyarakat yang sudah geram dengan tindak pidana korupsi. Kehadiran KPK untuk menjawab kebutuhan masyarakat akan adanya masalah korupsi yang kian massif di Indonesia (Zainal Arifin Mochtar, 2016: 85).

Perihal independensi KPK juga disampaikan oleh perwakilan pemerintah, yang menegaskan indepensi KPK adalah independensi institusional dan independensi fungsional, salah satu hal yang dituju dari pembentukannya adalah keharusan independensi kelembagaan, melalui unsur-unsur kelembagaannya yang dibuat menjadi independen (Zainal Arifin Mochtar, 2016: 85).

Dari beberapa pernyataan tersebut, keberadaan KPK sebagai lembaga negara independen adalah merupakan politik hukum dari para pembentuk undang- 


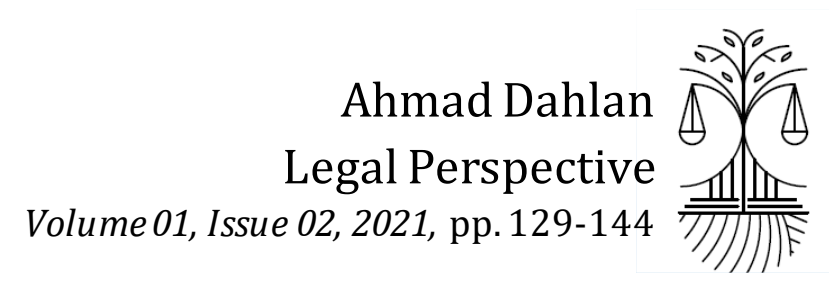

undang guna mewujudkan penyelenggaraan negara yang bersih dan bebas dari korupsi. Kedudukan KPK dalam struktur ketatanegaraan Indonesia adalah independen yang bebas dari campur tangan atau intervensi kekuasaan lain, serta berada di luar lingkup tiga cabang kekuasaan seperti klasifikasi teori trias politika, melainkan berada di luar tiga cabang kekuasaan tersebut yang berdiri terpisah.

Jika merujuk secara seksama risalah pembentukan Undang-Undang KPK, maka sangat terang bahwa status independensi KPK dimaksudkan untuk mempertegas keberadaannya yang tidak dapat diintervensi oleh kekuasaan lain, karena kedudukannya yang berada di luar cabang kekuasaan manapun, termasuk kedudukannya yang berada di luar lingkup kekuasaan Pemerintah. Seperti risalah pembentukan Undang-Undang KPK yang disebut di atas yang mempertegas sifat independensi KPK adalah independensi institusional yang berarti tidak memiliki garis kelembagaan yang terikat dengan kekuasaan manapun.

Lebih lanjut, untuk mempertegas independensi KPK yang secara yuridis pembentukan berada di luar lingkup kekuasaan Pemerintah, dapat dibaca secara seksama dari konsideran menimbang huruf (b) Undang-Undang KPK Nomor 30 Tahun 2002 yang menyatakan "bahwa lembaga pemerintah yang menangani perkara tindak pidana korupsi belum berfungsi secara efektif dan efisien dalam memberantas tindak pidana korupsi". Secara gramatikal, jika dimaknai secara utuh dan cermat, frasa lembaga pemerintah dalam konsideran tersebut mengindikasikan bahwa hendak dibentuk sebuah lembaga yang keberadaannya di luar atau bukan bagian dari lembaga pemerintah. Sebab, jika pembentuk Undang-Undang bermaksud membentuk KPK sebagai lembaga pemerintah, hemat penulis, seharusnya frasa yang digunakan dalam konsideran tersebut adalah menyebut secara eksplisit "kejaksaan dan kepolisian", tidak perlu menggunakan frasa "lembaga pemerintah". Frasa "lembaga pemerintah" dalam konsideran tersebut adalah penegasan dari pembentuk Undang-Undang terkait independensi kedudukan KPK yang bukan bagian dari lembaga pemerintah (eksekutif).

Memperjelas makna independensi secara substansi independensi yang harus dimiliki oleh lembaga negara independen setidaknya harus mencakup tiga ciri pokok: (1) independensi institusional atau struktural; (2) independensi fungsional; dan (3) independensi administratif (Jimly Asshiddiqie, 2008: 879880).

Salah satu ciri dari lembaga negara independen berdasarkan apa yang telah dijelaskan tersebut, ialah independensi secara institusional atau struktural, yang memiliki makna keberadaannya yang terpisah atau di luar dari lingkup 
kekuasaan eksekutif, legislatif, dan yudikatif. Artinya sebuah lembaga negara yang memiliki status independen, tidak dapat diklasifikasi ke dalam model trias politika. Hadirnya lembaga negara independen merupakan konsekuensi dari perkembangan ketatanegaraan modern, juga sebagai reaksi dari tuntutan masyarakat yang semakin kompleks dan dinamis yang tidak dapat dilakukan secara efisien dan efektif oleh tiga cabang lembaga negara berdasarkan doktrin ketatanegaraan klasik trias politika.

\section{Implikasi Putusan MK Nomor 36/PUU-XV/2017}

Secara normatif, Mahkamah Konstitusi dalam pengujian Undang- Undang adalah bersifat negative legislator (pembatal norma). Pada dasarnya MK bukan sebagai positive legislator (pembuat norma). Dalam putusannya terkait pengujian Undang-Undang terhadap UUD NRI 1945 (Constitutional Review), putusan MK yang menyatakan suatu Undang-Undang bertentangan dengan UUD NRI 1945 maka norma Undang-Undang tersebut tidak lagi mempunyai kekuatan hukum mengikat dan tidak dapat lagi diberlakukan. Konsekuensi dari putusan tersebut adalah semua warga negara mapun penyelenggara negara tidak dapat lagi merujuk pada norma undang-undang yang telah dibatalkan MK tersebut atau undang-undang lain yang mengatur hal yang sama, melainkan harus merujuk pada putusan MK, sebab putusan MK adalah memiliki posisi yang setara dengan Undang-undang (Husnu Abadi \& Wira Atma Hajri, 2017: 6).

Putusan MK bersifat final dan mengikat, artinya tidak ada lagi langkah hukum atau upaya hukum lain yang dapat dilakukan untuk menganulir kekuatan mengikat putusan MK. Kendati terdapat beberapa putusan MK yang mendapat berbagai kecaman dan penolakan, namun prinsip untuk menghargai setiap putusan hakim adalah prinsip fundamental dari ciri negara hukum. Ada implikasi hukum yang lahir dari putusan Mahkamah Konstitusi, termasuk putusan atas pengujian suatu norma Undang-Undang yang dinyatakan bertentangan dengan UUD NRI 1945.

Kehadiran putusan MK Nomor 36/PUU-XV/2017 sebagai konsekuensi atas pengujian norma Pasal 79 ayat (3) UU MD3 yang mengatur terkait penggunaan hak angket DPR terhadap Pemerintah (eksekutif). Para pemohon mengajukan pengujian norma pasal tersebut lantaran DPR membentuk panitia khusus untuk melakukan angket terhadap KPK. Para pemohon mendalilkan bahwa penggunaan angket DPR terhadap KPKadalah tidak tepat, sebab KPK bukanlah lembaga yang termasuk dalam kekuasaan eksekutif. Namun, dengan perbandingan empat banding lima komposisi dari hakim MK, terdapat lima orang hakim konstitusi menyatakan bahwa angket DPR terhadap KPK adalah 


\section{Ahmad Dahlan \\ Legal Perspective}

Volume 01, Issue 02, 2021, pp. 129-144

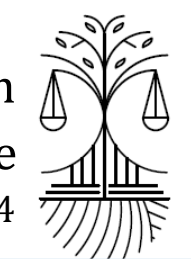

konstitusional, sebab KPK adalah lembaga negara dalam lingkup kekuasaan eksekutif. Sebaliknya, empat orang hakim konstitusi yang menyatakan bahwa penggunaan hak angket DPR terhadap KPK bertentangan dengan UUD NRI 1945. Sebagai konsekuensi dari putusan tersebut, permohonan para pemohon ditolak oleh MK. Dalam putusan nomor 36/PUU-XV/2017, MK menegaskan KPK sebagai lembaga negara yang menjalankan kekuasan Pemerintah dan berada dalam lingkup kekuasaan eksekutif.

Putusan MK tersebut, memberi gambaran tidak ada lagi lembaga negara yang keberadaannya di luar dari lingkup kekuasaan eksekutif, legislatif, dan yudikatif. Dengan putusan itu, MK mengukuhkan desain kelembagaan negara Indonesia dengan model trias politika. Namun, jika merujuk secara komprehensif dan originalintent ketentuan yang diatur dalam UUD NRI 1945, perihal keberadaan Badan Pemeriksa Keuangan (BPK) yang kedudukannya sejajar dengan DPR, DPD, MPR, (legislatif) MK dan MA (yudikatif), serta Presiden (eksekutif). Dilihat dari pemisahan poros kekuasaan tersebut, jelas BPK tidak berada dalam tiga rumpun kekuasaan itu. Melainkan keberadaan BPK terpisah atau di luar lingkup kekuasaan dalam model teori trias politika. Menurut Pasal 23E UUD NRI 1945, BPK merupakan salah satu lembaga negara yang bebas dan mandiri dalam memeriksa pengelolaan dan tanggung jawab keuangan negara.

Lebih lanjut, Asshiddiqie, menegaskan sekaligus meluruskan anggapan keliru yang mengklasifikasi dan mengidentikan BPK sebagai lembaga pemerintah, dengan menjelaskan kedudukan BPK tidak di atas pemerintah, tetapi juga tidak berada di bawah pemerintah, melainkan keberadaannya di luar pemerintah dan bersifat otonom atau independen. Dari kedudukan BPK dalam struktur ketatanegaraan Indonesia, dapat memberi gambaran terkait konsepsi dasar struktur kelembagaan negara Indonesia yang dimaksud oleh para perumus UUD NRI 1945 (Original Intent) yang tidak menganut secara kaku konsep kelembagaan trias politika, dalam arti konsepsi kelembagaan negara Indonesia tidak dapat hanya klasifikasi kedalam tiga poros cabang kekuasaan negara (Jimly Asshiddiqie, 2010:140).

Demikian halnya dengan lembaga negara independen yang keberadaannya dibentuk dengan dasar hukum Undang-Undang yang secara eksplisit menjelaskan sifat mandiri maupun independensinya dengan dasar hukum pembentukannya, tidak dapat diklasifikasi keberadaan dan kedudukannya dalam tiga cabang kekuasaan. Melainkan kedudukannya berada di luar dari tiga cabang kekuasaan tersebut. Hal itu dimaksudkan oleh para pembentuk Undang-Undang untuk menjaga kemandirian maupun independensi lembaga 
negara independen agar tidak dalam menjalankan tugas dan wewenangnya tidak diintervensi oleh lembaga negara lain.

Terdapat implikasi dari putusan Mahkamah Konstitusi Nomor 36/PUU$\mathrm{XV} / 2017$ terhadap kedudukan KPK sebagai lembaga negara independen dalam struktur ketatanegaraan Indonesia. Dalam hal ini, hemat penulis terdapat dua implikasi penting yang timbul dari putusan tersebut, yakni:

1. Kedudukan KPK sebagai lembaga negara independen

Implikasi dari putusan MK Nomor 36/PUU-XV/2017 ialah kedudukan KPK sebagai lembaga negara yang berada dalam lingkup kekuasaan eksekutif, menempatkan KPK sebagai lembaga eksekutif telah mereduksi dan bahkan menghilangkan indepensi KPK sebagai lembaga negara yang dalam melaksanakan tugas dan fungsinya tidak dapat diintervensi oleh kekuasaan manapun. Namun, dengan putusan ini KPK justru ditempatkan ke dalam lingkup kekuasaan eksekutif yang tidak saja menjadikan KPK sebagai objek angket DPR, akan tetapi dengan putusan ini KPK sebagai lembaga negara yang berada dalam lingkup kekuasaan eksekutif, artinya Presiden sebagai kepala eksekutif juga membawahi KPK. Hal ini jelas bertolak belakang dengan makna independensi, lebih-lebih makna independensi struktural atau institusional.

Kendati dalam putusan tersebut secara eksplisit masih mengakomodir frasa independensi KPK, namun hemat penulis, independensi tersebut tidak ada gunanya jika KPK diklasifikasi ke dalam rumpun kekuasaan eksekutif. Posisi KPK saat ini sebagai lembaga negara yang berada dalam lingkup kekuasaan eksekutif rentan dan berpotensi mengalami gangguan serta campur tangan dari kekuasaan pemerintah. Begitu pula DPR yang dapat sewaktu-waktu mengajukan angket, hak interpelasi dan hak mengajukan pendapat terhadap KPK yang dapat mengganggu efektifitas pelaksanaan tugas dan wewenang KPK dengan dalil hukum yang tidak mendasar. Karena hak-hak konstitusional DPR sewaktu-waktu dapat digunakan, maka dengan kesepakatan politik antara anggota fraksi, sudah dapat mengajukan hak interpelasi, hak angket dan/atau hak menyatakan pendapat terhadap semua lembaga negara yang berstatus independen yang dianggap "menyimpang" oleh DPR. Terkhusus KPK yang sudah terang dan telah secara massif menjerat anggota DPR atau kader-kader partai politik yang melakukan korupsi, kolusi, dan nepotisme yang merugikan keuangan negara. Lebih lanjut, sebagai tindak lanjut dari putusan MK tersebut ialah lahirnya Revisi Undang-Undang KPK yang mengatur keberadaan Dewan Pengawas KPK yang kelimanya diangkat oleh presiden sebagai kepala 


\section{Ahmad Dahlan \\ Legal Perspective}

Volume 01, Issue 02, 2021, pp. 129-144

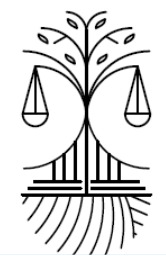

pemerintah. Keberadaan Dewan Pengawas dalam Undang-Undang tersebut ialah bentuk keterlibatan dan campur tangan pemerintah (eksekutif).

2. Kedudukan lembaga negara independen lain

Selain berimpimplikasi terhadap kedudukan KPK dalam struktur ketatanegaraan Indonesia, Putusan MK Nomor 36/PUU-XV/2017 tersebut juga berimplikasi terhadap kedudukan lembaga negara independen lainnya. Termasuk lembaga negara independen yang nama maupun fungsinya disebutkan dan/atau dijelaskan keberadaannya dalam UUD NRI 1945 (lembaga independen konstitusional), seperti Komisi Pemilihan Umum, Komisi Yudisial, Bank Indonesia, dan/atau lembaga negara independen yang dasar pembentukannya melalui Undang-Undang maupun peraturan di bawahnya.

Menempatkan KPK sebagai lembaga negara pemerintah (eksekutif) seperti dalam Putusan MK Nomor 36/PUU/2017, adalah tidak tepat serta bertentangan dengan motif awal perumusan norma pembentukan UndangUndang KPK. Hal itu juga bertentangan dengan konsep kelembagaan negara Indonesia, serta tidak sesuai dengan perkembangan ketatanegaraan modern yang tidak lagi menganut konsep pemisahan kekuasaan secara kaku seperti teori negara klasik yang memisah kekuasaan hanya pada tiga lingkup cabang kekuasaan (eksekutif, legislatif, dan yudikatif). Sebagaimana dalam penjelasan sebelumnya, ciri dari lembaga negara yang bersifat independen adalah berada di luar lingkup cabang kekuasaan trias politika.

\section{Kesimpulan}

Putusan MK Nomor 36/PUU-XV/2017 menafsirkan kedudukan kelembagaan KPK dengan merujuk pada teori pemisahan kekuasaan (Trias Politica) yang dipelopori oleh Baron Montesqiue abad ke-18. Dalam doktrin teori tersebut kekuasaan negara hanya dibagi ke dalam tiga lingkup kekuasaan yang terdiri dari lingkup kekuasaan eksekutif, legislatif, dan yudikatif. Mahkamah menilai tugas dan wewenang yang dijalankan oleh KPK adalah melaksanakan perintah undang-undang dalam melakukan penyelidikan, penyidikan serta penuntutan terhadap tindak pidana korupsi. Dalam teori trias politica klasik, fungsi-fungsi tersebut dilaksanakan oleh cabang kekuasaan pemerintah (eksekutif). Putusan tersebut jelas bertentangan dengan struktur ketatanegaraan Indonesia yang tidak menganut secara kaku teori trias politica, dan putusan $a$ quo juga bertentangan dengan dinamika ketatanegaraan modern, yang tidak lagi mengklasifikasi kekuasaan negara hanya ke dalam tiga cabang kekuasaan. Sebagai implikasi dari putusan MK Nomor 36/PUU-XV/2017, independensi KPK tidak lagi dapat dikatakan independen dalam arti yang sebenarnya (independensi institusional), kedudukan KPK sebagai lembaga eksekutif pada 
hakikatnya telah menghilangkan independensi kelembagaan KPK. Secara otomatis KPK menjadi lembaga yang berada di bawah naungan presiden sebagai kepala eksekutif. Pada prinsipnya semua lembaga pemerintah yang berada di bawah naungan presiden harus menyesuaikan diri dengan orientasi kebijakan strategis Presiden sebagai kepala pemerintahan (eksekutif).

\section{Referensi}

Abadi, M. Husnu. (2017). Pemuatan Norma Hukum yang Telah Dibatalkan oleh Mahkamah Konstitusi, Yogyakarta: Deepublish

Akbal, M. \& Rauf, Ahmad .(2018). Peran Mahkamah Konstitusi dalam Pembubaran Partai Politik, Surabaya: Media Sahabat Cendekia

Arifin Mochtar, Zainal. (2016). Lembaga Negara Independen: Dinamika Perkembangan dan Urgensi Penataannya Kembali Pasca-Amandemen Konstitusi, Jakarta: Rajawali Pers

Asshiddiqie, Jimly.(2010). Perkembangan dan Konsolidasi Lembaga Negara Pasca Reformasi, Jakarta: Sinar Grafika

Asshiddiqie, Jimly.(2012). Hukum Tata Negara dan Pilar-pilar Demokrasi, Jakarta: Sekretariat Jenderal Mahkamah Konstitusi Republik Indonesia.

Asshiddiqie, Jimly.(2015). Pengatar Ilmu Hukum Tata Negara, Jakarta: Rajawali Pers

Ayani, Mas Nyoman dan Hermanto Bagus, (2019). Gagasan Perluasan Lembaga Negara sebagai Pihak Pemohon dalam sengketa Kewenangan Antar Lembaga Negara di Mahkamah Konstitusi Republik Indonesia. Jurnal Legislasi Indonesia, 16(2). doi: http://e-jurnal.peraturan.go.id

Civitas Akademika Yogyakarta desak ketua MK mundur. Diakses pada tanggal 18 November 2019 dari https://news.detik.com/berita-jawatengah/d- 3878392/civitas-akademika-yogyakarta-desak-ketua-mkmundur

Effendy, Marwan. (2005). Kejaksaan RI: Posisi dan Fungsinya dari Perspektif Hukum, Jakarta: Gramedia Pustaka Utama

Huda, Ni'matul. (2005). Hukum Tata Negara Indonesia,Jakarta: Rajawali

Huda, Ni'matul. (2007) Lembaga Negara dalam masa Transisi Demokrasi, Jakarta:Sinar Grafika

Johan, Teuku Saiful Bahri. (2018) Hukum Tata Negara dan Hukum Administrasi Negara dalam Tataran Reformasi Ketatatnegaraan Indonesia, Yogyakarta: Deepublish

Kartayasa, Mansur. (2017). Korupsi dan Pembuktian Terbalik dari Perspektif Kebijakan Legislasi dan HakAsasi Manusia, Jakarta: Kencana

Lutfi, Mustafa. (2010). Hukum Sengketa Pemilukada di Indonesia, Yogyakarta: UII press 


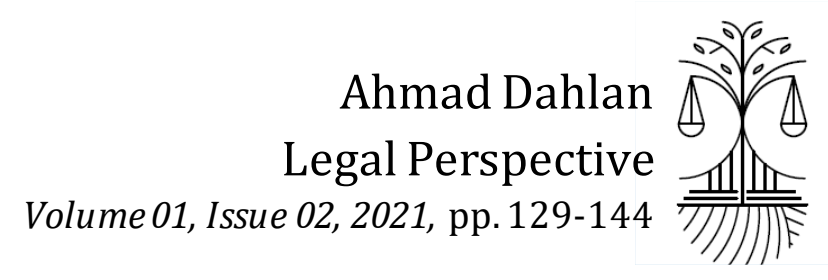

Malian, Sobirin.,\& H.M.Thalhah. (2011). Perkembangan Lembaga-lembaga Negara di Indonesia, Yogyakarta: Total media

Muhtadi, (2013). Lembaga Negara : makna, kedudukan dan relasi. Jurnal Ilmu Hukum,7 (3). doi: http://doi.org/10.25041/flatjustisia.v7no3.384

Napitupulu, Diana. (2010). KPK in Action, Jakarta: Raih Asah Sukses

Putusan Mahkamah Konstitusi Nomor 36/PUU-XV/2017

Sejumlah peraturan perundang-undangan terkait Komisi Pemberantasan $\begin{array}{lllll}\text { Korupsi. } & \text { Diakses } & 26 & \text { September } & 2019\end{array}$ https://www.kpk.go.id/id/tentang-kpk/undang- undang-terkait Selama jabat ketua MK, Arif Hidayat dua kali langgar kode etik. Diakses pada tanggal 18 November, 2019 dari https://nasional.kompas.com/read/2018/01/16/16393731/selamajabat-

Setiawan, Ahmad., Fitriani, Irmauchtar., \& Haboddin, Muchtar. (2015). Pengantar State Auxliary Agency, Malang: UB Press

Sugianto. (2018) Ilmu Negara:Sebuah Kajian Dalam Perspektif Teori Kenegaraan di Indonesia Yogyakarta: Deepublish

Sulistiyono, Adi \& Isharyanto. (2018). Sistem Peradilan di Indonesia dalam teori dan Praktik, Depok: Prenadamedia Group

Tauda, Gunawan A. (2011). Kedudukan Komisi Negara Independen Dalam Struktur Ketatanegaraan Indonesia, Pranata Hukum

Undang Undang Dasar Negara Republik Indonesia 1945.

Undang-undang No. 28 Tahun 1999 tentang Penyelenggaraan Negara Yang Bersih Dan Bebas Dari Korupsi, Kolusi, Dan Nepotisme.

Undang-Undang No.19 Tahun 2019 tentang Perubahan atas Undang-Undang No.30 Tahun 2002 tentang Komisi Pemberantasan Korupsi.

Undang-Undang No.20 Tahun 2001 tentang Perubahan atas Undang-Undang No.31 Tahun 1999 tentang Pemberantasan Tindak Pidana Korupsi.

Undang-Undang No.30 Tahun 2002 tentang Komisi Pemberantasan Korupsi. Undang-Undang No.31 Tahun 1999 tentang Pemberantasan Tindak Pidana Korupsi.

Wardojo, Mellysa Febriani. (2018). Kedudukan Komisi Pemberantasan Korupsi sebagai Lembaga Negara. Jurnal Hukum Legal Standing, 2(1). doi: http://journal.umpa.ac.id 